\title{
Analisis Pengukuran Kualitas Penggunaan Sistem Informasi Akademik (Studi Kasus Sistem Informasi Akademik STIQ Al-Lathifiyyah Palembang)
}

\author{
Johan Hafasri ${ }^{1}$, M Haviz Irfani ${ }^{2}$, Fathiyah Nopriani ${ }^{3}$ \\ johan.hafasri92@yahoo.com ${ }^{1}$, haviz.irfani@gmail.com² ${ }^{2}$, fathiyahnopriani_uin@ radenfatah.ac.id $^{3}$ \\ 1Sistem Informasi, Fakultas Sains dan Teknologi, UIN Raden Fatah Palembang
${ }^{2}$ Sistem Informasi, Fakultas Sains dan Teknologi, UIN Raden Fatah Palembang
${ }^{3}$ Sistem Informasi, Fakultas Sains dan Teknologi, UIN Raden Fatah Palembang
}

Diterima: 07 Oktober 2019 | Direvisi: 12 November 2019| Disetujui: 30 Desember 2019

(C) 2019 Program Studi Sistem Informasi Fakultas Sains dan Teknologi,

Universitas Islam Negeri Raden Fatah Palembang, Indonesia

\begin{abstract}
Abstrak: Teknologi informasi pada era globalisasi ini, telah membawa banyak perubahan yang begitu cepat di berbagai bidang dan pihak. Pemanfaatan teknologi informasi ini memberikan berbagai kemudahan untuk memperoleh informasi dan membantu menyelesaikan. Sekolah Tinggi Ilmu Al- Qur'an (STIQ) Al-Lathifiyyah merupakan salah satu perguruan tinggi di Palembang yang telah memanfaatkan teknologi informasi dalam mengelola kegiatan data akademik yang biasa dikenal sebagai Sistem Informasi Akademik (SIAKAD). Diketahui bahwa, pihak STIQ Al-Lathifiyyah khususnya di bagian pengembang sistem sejak berdirinya SIAKAD STIQ Al-Lathifiyyah ini belum pernah ada penelitian tentang analisis dan melakukan pengukuran kualitas penggunaannya. Hal ini tentu saja dapat menimbulkan ketidaktahuan akan kualitas dari SIAKAD yang mereka kelola bagi para penggunanya. Untuk melakukan analisis pengukuran kualitas penggunaan tersebut akan mengacu pada standarisasi ISO/IEC 9126-4 Quality In Use dengan berdasarkan faktor effectiveness, productivity, safety dan satisfaction. Hasil dari penelitian ini adalah effectiveness metrics dengan nilai 0,8838 termasuk ke dalam kategori high, productivity metrics dengan nilai 0,8744 termasuk ke dalam kategori high, safety metrics dengan nilai 0,1650 termasuk ke dalam kategori low, dan satisfaction metrics dengan nilai 0,4147 termasuk ke dalam kategori medium. Hal ini membuktikan bahwa SIAKAD STIQ Al-Lathifiyyah Palembang sudah memenuhi standarisasi suatu sistem informasi akademik yang baik berdasarkan model ISO/IEC 9126-4 quality in use metrics.
\end{abstract}

Kata Kunci: Kualitas Sistem, ISO/IEC 9126-4, SIAKAD STIQ Al-Lathifiyyah Palembang

\begin{abstract}
Information technology in this era of globalization, has brought many changes so quickly in various fields and parties. Utilization of information technology provides various facilities to obtain information and help solve it. Al-Lathifiyyah Al-Qur'an School of Science (STIQ) is one of the universities in Palembang that has utilized information technology in managing academic data activities commonly known as Academic Information Systems (SIAKAD). It is known that, the STIQ AlLathifiyyah especially in the part of the system developer since the establishment of SIAKAD STIQ AlLathifiyyah, there has never been any research on analysis and measuring the quality of its use. This of course can lead to ignorance of the quality of SIAKAD that they manage for its users. To conduct an analysis of the measurement of the quality of use will refer to the standardization of ISO / IEC 9126-4 Quality in Use based on the factors of effectiveness, productivity, safety and satisfaction. The results of this study are the effectiveness metrics with a value of 0.8838 included in the high category, productivity metrics with a value of 0.8744 included in the high category, safety metrics with a value of 0.1650 included in the low category, and satisfaction metrics with a value of 0,4147 included in the medium category. This proves that SIAKAD STIQ Al-Lathifiyyah Palembang has fulfilled the standardization of a good academic information system based on the ISO / IEC 9126-4 quality in use metrics model. Keywords: System Quality, ISO/IEC 9126-4, SIAKAD STIQ Al-Lathifiyyah Palembang
\end{abstract}




\section{PENDAHULUAN}

Teknologi informasi pada era globalisasi ini, telah membawa banyak perubahan yang begitu cepat di berbagai bidang dan pihak. Pemanfaatan teknologi informasi ini memberikan berbagai kemudahan untuk memperoleh informasi, membantu menyelesaikan pekerjaan dan juga memberikan layanan secara maksimal kepada pengguna. Ketergantungan pada teknologi informasi ini mengharuskan perangkat lunak berfungsi dengan benar dan cara kerjanya. Secara umum, berbagai persyaratan untuk perangkat lunak yang berkualitas tinggi harus disetujui oleh orang-orang yang terlibat dalam pengembangan dan dukungan sistem perangkat lunak melalui berbagai kegiatan penjaminan mutu, sedangkan untuk klaim kualitas yang sangat baik membutuhkan dukungan dari bukti yang didasarkan pada analisis dan pengukuran yang konkret (Sidik, 2018).

Sekolah Tinggi Ilmu Al-Qur'an (STIQ) Al-Lathifiyyah merupakan salah satu perguruan tinggi di Palembang yang telah memanfaatkan teknologi informasi dalam mengelola kegiatan data akademik yang biasa dikenal sebagai Sistem Informasi Akademik (SIAKAD) berbasis web. Adapun fungsi-fungsi yang terdapat pada SIAKAD STIQ Al-Lathifiyyah diantaranya adalah mengambil jadwal mata kuliah dan mencetaknya, melihat kartu hasil studi dan mencetaknya, melihat transkrip nilai dan mencetaknya serta melihat info perkuliahan dan pengumuman terkait kemahasiswaan. Hal ini tentunya dapat memudahkan mahasiswa dan dosen dalam mengakses informasi perkuliahan tanpa harus datang langsung ke kampus. Dalam hasil observasi dengan ketua UPT LITBANG di STIQ Al-Lathifiyyah beliau mengatakan bahwasanya, SIAKAD akan dapat berjalan dengan baik apabila komponen atau fungsi yang ada pada SIAKAD ini bekerja dengan baik. Sebaik-baiknya dan dengan penggunaan peralatan yang canggih sekalipun dalam pengembangan sistem, apabila infrastruktur dan sumber daya manusianya tidak mendukung maka akan menjadi tidak efektif penggunaan sistem tersebut. Selain membantu dalam proses belajar mengajar, penggunaan SIAKAD juga dapat dijadikan indikator keberhasilan pengelolaan pembelajaran online.

Sehubungan dengan itu banyaknya tugas dan fungsi yang harus dilakukan SIAKAD STIQ Al-Lathifiyyah serta berdasarkan hasil wawancara dan observasi yang telah peneliti lakukan. Diketahui bahwa, pihak STIQ Al-Lathifiyyah khususnya di bagian pengembang sistem sejak berdirinya SIAKAD STIQ Al-Lathifiyyah ini belum pernah ada penelitian tentang analisis dan melakukan pengukuran kualitas penggunaannya. Hal ini menimbulkan ketidaktahuan akan kualitas dari SIAKAD yang mereka kelola bagi para penggunanya, maka perlu dilakukan analisis dan pengukuran kualitas yang bertujuan untuk mengetahui apakah sistem informasi akademik yang digunakan sudah sesuai dan memenuhi standar kualitas yang ada. Untuk mengetahui kualitas dari pelayanan suatu sistem maka dibutuhkan pengukuran yang didasarkan pada respon atau tanggapan para pengguna yang berinteraksi langsung dengan sistem, sehingga data dari pengguna tersebut diharapkan sesuai dan dapat dilakukan pengukuran serta evaluasi kualitas sistem (Sidik, 2018).

Pengukuran tersebut menggunakan ISO/IEC 9126-4 Quality in Use Metrics. ISO/IEC 9126 adalah standar internasional yang diterbitkan oleh ISO kemudian dikembangkan pada tahun 1985, untuk evaluasi kualitas perangkat lunak dan merupakan pengembangan dari ISO 9001. ISO/IEC 9126 dibagi menjadi 4 bagian yaitu Model Kualitas (Quality Metrics) yang disebut ISO/IEC 9126-1, Metrik Eksternal (External Metrics) yang disebut ISO/IEC 9126-2, Metrik Internal (Internal Metrics) yang disebut ISO/IEC 9126-3, Metrik Kualitas Penggunaan (Quality In Use Metrics) yang disebut ISO/IEC 9126-4 (Djoub \& Bari, 2016).

Berdasarkan latar belakang yang telah diuraikan, penulis tertarik untuk melakukan analisis kualitas penggunaan SIAKAD di STIQ Al-Lathifiyyah Palembang dengan menggunakan model ISO/IEC 9126-4. Analisis ini diharapkan dapat membantu pihak pengembang untuk mengetahui kualitas dari SIAKAD. Dan juga dapat digunakan sebagai keperluan dan acuan untuk tindakan pengembangan sistem informasi yang lebih baik kedepannya. 


\section{METODOLOGI PENELITIAN}

\subsection{Metode Penelitian}

Metode penelitian pada penelitian ini adalah pendekatan kuantitatif. Penelitian ini bersifat deskriptif kuantitatif dan menggunakan teknik pengumpulan data seperti kuesioner, wawancara dan observasi untuk mendapatkan data yang dibutuhkan. Untuk itu penulis menggunakan instrumen penelitian uji validitas dan uji reliabilitas digunakan untuk mengukur variabel yang telah ditetapkan. Data yang telah terkumpul selanjutnya di analisis, analisis diarahkan untuk menjawab dari rumusan masalah. Dari data hasil analisis selanjutnya disajikan dan diberikan pembahasan, setelah itu dapat disimpulkan dan memberikan saran.

\subsection{ISO/IEC 9126-4 Quality in Use Metrics}

Menurut ISO/IEC FDIS 9126-1 (Anonim, ISO/IEC 9126-1: Information Technology Software Product Quality - Part 1: Quality Model, 2000), ISO/IEC 9126-4 Quality In Use Metrics adalah pandangan terhadap kualitas dari suatu produk perangkat lunak pada saat digunakan dalam lingkungan yang spesifik dan konteks penggunaan tertentu. Bagian ini menjelaskan metrik kualitas penggunaan yang digunakan untuk mengukur karakteristik kualitas perangkat lunak pada saat produk perangkat lunak dapat dieksekusi dan telah melewati proses operasi perangkat lunak. Metrik-metrik dalam model ISO/IEC 9126 dapat dievaluasi menggunakan pengukuran langsung atau tidak langsung dengan mengukur konsekuensi. Sebagai contoh, sebuah proses yang akan dinilai langsung dengan mengukur dan mengevaluasi produk, sedangkan produk yang dievaluasi secara tidak langsung mengukur kinerja tugas pengguna (menggunakan quality in use metrics). Metrik ini berfokus mengukur sejauh mana pengguna dapat mencapai tujuan mereka dalam lingkungan tertentu, dari pada mengukur sifat dari perangkat lunak itu sendiri. Untuk mencapai metrik ini bergantung pada pencapaian kualitas eksternal yang diperlukan, yang pada gilirannya tergantung pada pencapaian kualitas internal yang diperlukan. Adapun model kualitas dari Quality in Use Metrics dapat dilihat pada Gambar 1.

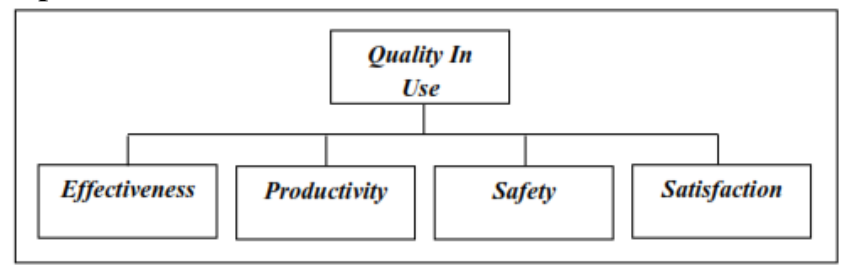

Gambar 1. Model Quality in Use

Sumber: (Anonim, ISO/IEC 9126-1: Information Technology - Software Product Quality Part 1: Quality Model, 2000)

\subsubsection{Effectiveness Metrics}

Menurut ISO/IEC 9126-4 (Anonim, ISO/IEC 9126-4: Software Engineering - Software Product Quality - Part 4: Quality in Use Metrics, 2001), pengujian metrik efektifitas dilakukan untuk mengukur akurasi dan kelengkapan berdasarkan dari tujuan yang dicapai, pengujian ini dilakukan oleh responden dengan cara mengujikan setiap fitur-fitur yang ada pada SIAKAD. Metrik ini menilai apakah tugas yang dilakukan oleh pengguna mencapai tujuan-tujuan tertentu dengan ketepatan dan kelengkapan dalam konteks penggunaan tertentu.

\subsubsection{Productivity Metrics}

Menurut ISO/IEC 9126-4 (Anonim, ISO/IEC 9126-4: Software Engineering - Software Product Quality - Part 4: Quality in Use Metrics, 2001), ukuran produktivitas berhubungan dengan tingkat efektivitas yang dicapai pada pengeluaran sumber daya. Pengukuran productivity metrics dilakukan dengan menggunakan skenario pengujian yang berfokus kepada sumber daya yang digunakan oleh responden untuk menyelesaikan sebuah skenario 
diantaranya yaitu waktu pengujian dan jumlah pengujian yang dilakukan. Sumber daya yang relevan dapat mencangkup usaha mental, fisik, waktu, materi atau biaya finansial.

\subsubsection{Safety Metrics}

Menurut ISO/IEC 9126-4 (Anonim, ISO/IEC 9126-4: Software Engineering - Software Product Quality - Part 4: Quality in Use Metrics, 2001), tindakan keamanan berhubungan dengan risiko pengoperasian produk perangkat lunak dari waktu ke waktu, kondisi penggunaan dan konteks penggunaan. Keselamatan dapat dianalisis dalam hal keselamatan operasional dan keamanan. Metrik keamanan menilai tingkat risiko kerugian bagi orangorang, bisnis, perangkat lunak, properti atau lingkungan dalam konteks penggunaan tertentu. Termasuk kesehatan dan keselamatan pengguna dan pihak yang terpengaruh oleh penggunaan. Untuk mengukur safety metrics dilakukan dengan cara observasi dan wawancara kepada narasumber untuk memperoleh tingkat keamanan pada SIAKAD. Hasil dari observasi diolah dan dianalisis dengan menggunakan risk matrix.

\subsubsection{Satisfaction Metrics}

Menurut ISO/IEC 9126-4 (Anonim, ISO/IEC 9126-4: Software Engineering - Software Product Quality - Part 4: Quality in Use Metrics, 2001), kepuasan menggambarkan respon subjektif pengguna saat menggunakan produk. Kepuasan pengguna mungkin merupakan korelasi penting dari motivasi untuk menggunakan produk dan dapat mempengaruhi kinerja dalam beberapa kasus. Kuesioner untuk mengukur kepuasan dan keterkaitannya umumnya dibangun dengan menggunakan skala Likert, kuesioner pada penelitian ini menggunakan model PSSUQ. Metrik kepuasan menilai sikap pengguna terhadap penggunaan produk dalam konteks penggunaan tertentu. Dengan catatan bahwa kepuasan dipengaruhi oleh persepsi pengguna tentang sifat produk perangkat lunak (seperti yang diukur oleh metrik eksternal) dan persepsi pengguna terhadap efisiensi, produktivitas dan keamanan yang digunakan.

\subsection{Populasi dan Sampel}

\subsubsection{Populasi}

Populasi yang digunakan dalam penelitian ini adalah seluruh sampel yang didapat. Responden dalam penelitian ini adalah mahasiswa, dosen dan admin sebagai pengguna dari SIAKAD STIQ Al-Lathifiyyah Palembang yang berjumlah 72 orang, dapat dilihat pada Tabel 1.

Tabel 1. Data Populasi

\begin{tabular}{|c|l|c|}
\hline No. & \multicolumn{1}{|c|}{ Populasi } & Jumlah Populasi \\
\hline 1. & Mahasiswa/i & 61 \\
\hline 2. & Dosen & 9 \\
\hline 3. & Admin & 2 \\
\hline \multicolumn{2}{|c|}{ Total Populasi } & $\mathbf{7 2}$ \\
\hline
\end{tabular}

\subsubsection{Sampel}

Dalam penelitian ini penulis menggunakan teknik sampel sampling jenuh, dikarenakan jumlah populasi yang ada pada STIQ Al-Lathifiyyah Palembang yaitu sebanyak 72 orang responden. Menurut (Arifin, 2017), sampling jenuh merupakan teknik pengambilan sampel yang digunakan pada populasi yang semua anggotanya digunakan sebagai sampel, jika populasinya kurang dari 100 orang. 


\subsection{Tahapan Penelitian}

Tahapan penelitian menggambarkan proses penelitian yang akan ditempuh sekaligus menggambarkan penelitian secara keseluruhan. Tahapan penelitian dapat dilihat pada Gambar 2.

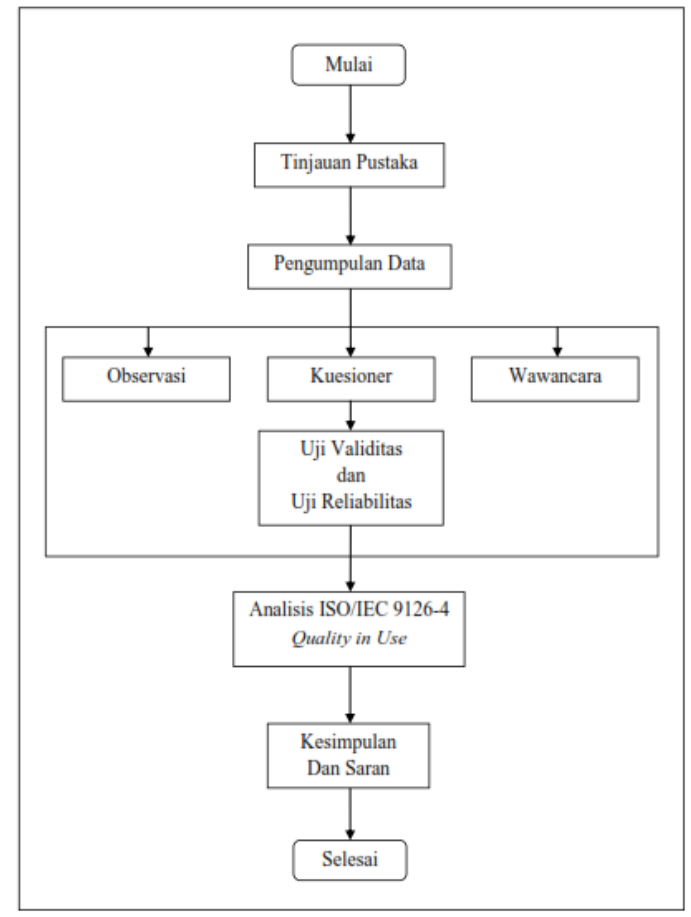

Gambar 2. Tahapan Penelitian

\subsection{Analisis Penilaian ISO/IEC 9126-4 Quality in Use Metrics}

Analisis penilaian ini bertujuan untuk mendapatkan nilai faktor, subfaktor dan nilai pembobotan. Pembobotan dilakukan pada faktor, subfaktor dan kriteria yang didapat dari hasil pengolahan data. Adapun penilaian dalam penelitian ini dilakukan dengan menggunakan metode Rank Order Centroid (ROC). ROC didasarkan pada tingkat kepentingan atau prioritas dari kriteria, teknik ini memberikan bobot pada setiap kriteria sesuai dengan ranking yang dinilai berdasarkan tingkat prioritas. Biasanya dibentuk dengan pernyataan "Kriteria 1 lebih penting dari kriteria 2, yang lebih penting dari kriteria 3" dan seterusnya hingga kriteria ke $n$ ditulis. Untuk menentukan prioritasnya, diberikan aturan yaitu dimana nilai tertinggi merupakan nilai yang paling penting diantara nilai yang lainnya (Astiani, Andreswari, \& Setiawan, 2016). Dapat dilihat pada penjelasan berikut ini:

Jika:

$\mathrm{Cr}_{1}>\mathrm{Cr}_{2}>\mathrm{Cr}_{3}>\ldots>\mathrm{Cr}_{\mathrm{n}}$

Maka,

$\mathrm{W}_{1}>\mathrm{W}_{2}>\mathrm{W}_{3}>\ldots>\mathrm{W}_{\mathrm{n}}$

Selanjutnya, jika k merupakan banyaknya kriteria, maka:

$$
\begin{aligned}
& W_{1}=\frac{1+\frac{1}{2}+\frac{1}{3}+\ldots+\frac{1}{k}}{k} \\
& W_{2}=\frac{0+\frac{1}{2}+\frac{1}{3}+\ldots+\frac{1}{k}}{k}
\end{aligned}
$$


$W_{3}=\frac{0+0+\frac{1}{3}+\ldots+\frac{1}{k}}{k}$

$W_{k}=\frac{0+\ldots+0+\frac{1}{k}}{k}$

Secara umum pembobotan $R O C$ dapat dirumuskan sebagai berikut:

$W_{k}=\frac{1}{k} \sum_{i=1}^{k}\left(\frac{1}{k}\right)$

Setelah mendapatkan nilai pembobotan, maka selanjutnya membandingkan nilai tersebut dengan kriteria yang telah ditetapkan dari model ISO/IEC 9126-4 quality in use metrics yaitu nilai minimal adalah 0 dan nilai maksimal adalah 1 . Model ini juga membagi penilaian ke dalam 3 kategori yaitu high, medium, dan low. Oleh karena itu, diperlukan range untuk masing-masing kategori guna untuk dapat membuat kesimpulan dari nilai yang didapat, berikut range nilai yang ada pada model ISO/IEC 9126-4 Quality in Use Metrics.

Tabel 2. Range Nilai Model ISO/IEC 9126-4 Quality in Use Metrics

\begin{tabular}{ccc} 
Bobot & Range Nilai & Nilai Tengah \\
\hline Low & $0-0.330$ & 0.165 \\
Medium & $0.344-0.670$ & 0.505 \\
High & $0.680-1$ & 0.850
\end{tabular}

Sumber: (Anonim, ISO/IEC 9126-4: Software Engineering - Software Product Quality - Part 4: Quality in Use Metrics, 2001)

Untuk setiap faktor kualitas yang ada pada ISO/IEC 9126-4 Quality in Use Metrics, tentunya memiliki kategori pengukuran yang dijadikan standarisasi kualitas suatu perangkat lunak yang baik. Tabel berikut menampilkan kriteria standar suatu perangkat lunak berdasarkan ISO/IEC 9126-4 Quality in Use Metrics.

Tabel 3. Kategori Pengukuran Quality in Use Metrics

\begin{tabular}{l|cc}
\hline \multicolumn{3}{c}{ Kategori Pengukuran } \\
\hline \multirow{4}{*}{ Quality in Use } & Karakteristik in & $\begin{array}{c}\text { Bobot } \\
\text { (High, Medium, Low) }\end{array}$ \\
\cline { 2 - 3 } & Effectiveness & $\mathrm{H}$ \\
& Productivity & $\mathrm{H}$ \\
& Safety & $\mathrm{L}$ \\
& Satisfaction & $\mathrm{M}$ \\
\hline
\end{tabular}

Sumber: (Anonim, ISO/IEC 9126-4: Software Engineering - Software Product Quality - Part 4: Quality in Use Metrics, 2001)

\section{HASIL DAN PEMBAHASAN}

\subsection{Use Case Diagram SIAKAD STIQ Al-Lathifiyyah Palembang}

Berikut ini merupakan Use Case Diagram yang digunakan dalam penelitian ini, dapat dilihat pada Gambar 3 . 


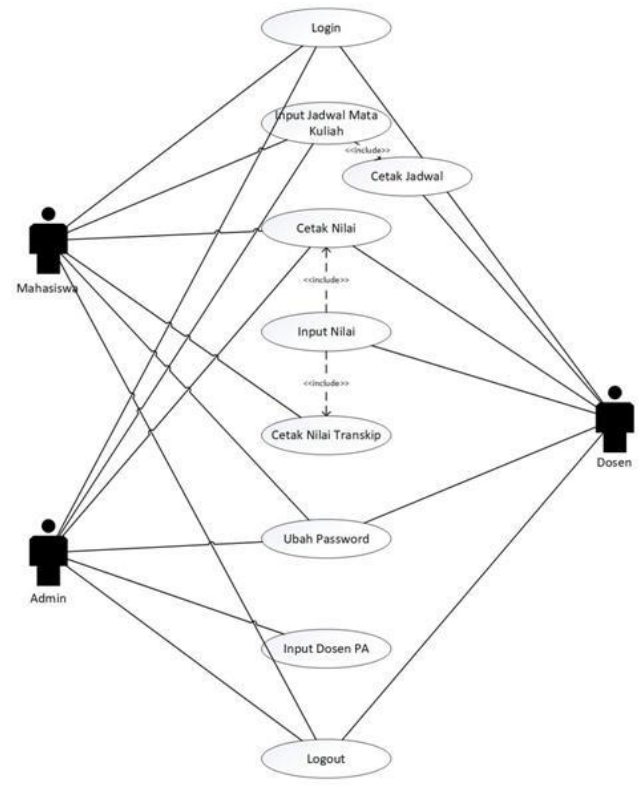

Gambar 3. Use Case Diagram SIAKAD STIQ Al-Lathifiyyah Palembang

\subsection{Uji Validitas dan Uji Reliabilitas}

\subsubsection{Uji Validitas}

Uji validitas dilakukan menggunakan teknik korelasi product moment dengan mengkorelasikan masing-masing pertanyaan dengan jumlah skor yang ada pada kuesioner. Angka kolerasi yang diperoleh secara statistik harus dibandingkan dengan angka kritik tabel kolerasi nilai $\mathrm{r}$ dengan taraf signifikan 95\% dengan disebarkan sebanyak 30 responden. Pertanyaan dinyatakan valid ketika $r_{\text {hitung }}>r_{\text {tabel }}$.

Tabel 4. Hasil Uji Validitas Instrumen dengan Teknik Product Moment

\begin{tabular}{cccc} 
Pernyataan & $\mathbf{r}_{\text {hitung }}$ & $\mathbf{r}_{\text {tabel }}$ & Keterangan \\
\hline X1 & 0.760 & 0.361 & Valid \\
X2 & 0.494 & 0.361 & Valid \\
X3 & 0.754 & 0.361 & Valid \\
X4 & 0.712 & 0.361 & Valid \\
X5 & 0.755 & 0.361 & Valid \\
X6 & 0.829 & 0.361 & Valid \\
X7 & 0.715 & 0.361 & Valid \\
X8 & 0.733 & 0.361 & Valid \\
X9 & 0.795 & 0.361 & Valid \\
X10 & 0.563 & 0.361 & Valid \\
X11 & 0.740 & 0.361 & Valid \\
X12 & 0.877 & 0.361 & Valid \\
X13 & 0.824 & 0.361 & Valid \\
X14 & 0.801 & 0.361 & Valid \\
X15 & 0.852 & 0.361 & Valid
\end{tabular}




\begin{tabular}{cccc}
\hline Pernyataan & $\mathbf{r}_{\text {hitung }}$ & $\mathbf{r}_{\text {tabel }}$ & Keterangan \\
\hline X16 & 0.669 & 0.361 & Valid \\
X17 & 0.654 & 0.361 & Valid \\
X18 & 0.737 & 0.361 & Valid \\
X19 & 0.816 & 0.361 & Valid \\
\hline
\end{tabular}

\subsubsection{Uji Reliabilitas}

Uji reliabilitas dilakukan terhadap pernyataan yang sudah valid dengan menggunakan teknik Cronbach's Alpha, syarat untuk menyatakan item tersebut reliabel adalah dengan melihat jika hasil uji reliabilitas lebih dari nilai Cronbach's Alpha 0,60 maka item tersebut dinyatakan reliabel.

Tabel 5. Hasil Uji Reliabilitas Instrumen Teknik Cronbach's Alpha

\begin{tabular}{cccc}
\hline No. & Variabel & Cronbach's Alpha & Keterangan \\
\hline 1. & Overall & 0,954 & Konsisten \\
2. & Sysue & 0,893 & Konsisten \\
3. & Infoqual & 0,914 & Konsisten \\
4. & Interqual & 0,753 & Konsisten \\
\hline
\end{tabular}

\subsection{Hasil Penelitian Terhadap Standar ISO/IEC 9126-4}

Setelah menganalisa hasil pengujian, observasi, dan kuesioner, hasil yang didapat kemudian digabungkan dan dibandingkan dengan tingkat yang dibutuhkan sesuai dengan standar ISO/IEC 9126-4 Quality in Use Metrics. Berikut tabel perbandingan hasil penelitian.

Tabel 6. Perbandingan Hasil Penelitian Terhadap Standar ISO/IEC 9126-4

\begin{tabular}{|c|c|c|c|}
\hline Metrik & Hasil & Kategori & Kriteria ISO/IEC 9126-4 \\
\hline Effectiveness & 0.8838 & High & High \\
\hline Productivity & 0.8744 & High & High \\
\hline Safety & 0.1650 & Low & Low \\
\hline Satisfaction & 0.4147 & Medium & Medium \\
\hline
\end{tabular}

Berdasarkan Tabel 6, diketahui bahwa SIAKAD STIQ Al-Lathifiyyah Palembang sudah memenuhi persyaratan standarisasi dari model ISO/IEC 9126-4. Hal ini terlihat dari keempat metrik yang ada, memiliki hasil sesuai dengan tingkat kebutuhan dari standar ISO/IEC 9126-4.

\subsubsection{Kualitas SIAKAD dari Sisi Effectiveness Metrics}

Berdasarkan hasil pengujian yang telah dilakukan, diperoleh hasil Effectiveness Metrics dengan tingkat high atau dengan angka sebesar 0,8838 dari skala pengukuran 0 hingga 1 . Dari nilai tersebut diketahui bahwa efektivitas penggunaan SIAKAD adalah sangat efektif, tingkat keefektifan yang diperoleh ini hanya diukur berdasarkan fungsi-fungsi yang telah ada pada SIAKAD.

\subsubsection{Kualitas SIAKAD dari Sisi Productivity Metrics}

Berdasarkan hasil pengujian yang telah dilakukan, diperoleh hasil Productivity Metrics dengan tingkat high atau dengan angka produktivitas sebesar 0,8744 dari skala pengukuran 0 hingga 1. Dari nilai tersebut diketahui bahwa produktivitas penggunaan SIAKAD adalah sangat produktif. 


\subsubsection{Kualitas SIAKAD dari Sisi Safety Metrics}

Berdasarkan hasil observasi yang telah dilakukan, diperoleh hasil Safety Metrics dengan tingkat low atau dengan angka keamanan sebesar 0,1650 dari skala pengukuran 0 hingga 1 . Tingkat keamanan ini diketahui secara langsung melalui wawancara kepada Kepala UPT LITBANG yang didasarkan pada subfaktor Safety Metrics yaitu User Health And Safety, Safety of People Affected by Use of The System, Economic Damage, dan Software Damage. Berdasarkan hasil dari keempat subfaktor tersebut, diketahui bahwa keamanan dari SIAKAD sangatlah aman. Walaupun demikian, peneliti mengharapkan agar penjagaan terhadap SIAKAD tetap dipertahankan bila perlu ditingkatkan, terutama pada kasus serangan virus ataupun hacker.

\subsubsection{Kualitas SIAKAD dari Sisi Satisfaction Metrics}

Berdasarkan pengolahan data yang didapat dari hasil kuesioner pada faktor Satisfaction Metrics, diketahui bahwa kepuasan pengguna terhadap SIAKAD berada pada tingkat medium atau dengan angka kepuasan sebesar 0,4147 dari skala 0 hingga 1 . Tingkat kepuasan ini dipengaruhi oleh fitur-fitur pada SIAKAD yang belum sepenuhnya dapat membuat penggunanya merasa puas. Adapun fitur utama yang terdapat pada SIAKAD yakni pengolahan data mahasiswa, data dosen, data admin, data kartu rencana studi, data kartu hasil studi, transkrip nilai, penjadwalan perkuliahan, serta dosen pembimbing akademik.

\section{KESIMPULAN}

Berdasarkan hasil dan pembahasan dari bab sebelumnya, maka kesimpulan dapat dirumuskan sebagai berikut:

1. Pengukuran kualitas SIAKAD STIQ Al-Lathifiyyah Palembang dilakukan dengan cara pengujian SIAKAD dan pengisian kuesioner yang dilakukan oleh responden yakni mahasiswa, dosen, dan admin serta observasi terhadap keamanan komputer server. Data yang didapat kemudian dianalisa dan dihitung menggunakan rumus yang ada pada model ISO/IEC 9126-4 Quality in Use Metrics.

2. Kualitas SIAKAD STIQ Al-Lathifiyyah Palembang sudah memenuhi keseluruhan aspek yang baik berdasarkan standar yang ada pada model ISO/IEC 9126-4 Quality in Use Metrics. Adapun hasil yang didapat dari keempat faktor yaitu Effectiveness Metrics termasuk ke dalam kategori high dengan nilai 0,8838, Productivity Metrics termasuk ke dalam kategori high dengan nilai 0,8744, Safety Metrics termasuk ke dalam kategori low dengan nilai 0,1650 dan Satisfaction Metrics termasuk ke dalam tingkat medium dengan nilai 0,4147 .

\section{DAFTAR RUJUKAN}

Anonim. (2000). ISO/IEC 9126-1: Information Technology - Software Product Quality - Part 1: Quality Model. ISO/IEC.

Anonim. (2001). ISO/IEC 9126-4: Software Engineering - Software Product Quality - Part 4: Quality in Use Metrics. ISO/IEC.

Arifin, J. (2017). SPSS 24 untuk Penelitian dan Skripsi. Jakarta: Elex Media Komputindo.

Astiani, N., Andreswari, D., \& Setiawan, Y. (2016). Aplikasi Sistem Pendukung Keputusan

Tanaman Obat Herbal Untuk Berbagai Penyakit Dengan Metode ROC (Rank Order

Centroid) dan Metode Oreste Berbasis Mobile Web. Informatika: Jurnal Teknologi

Komputer dan Informatika, 125-140. 
90 | JUSIFO (Jurnal Sistem Informasi), p-ISSN: 2460-092X, e-ISSN: 2623-1662

Djoub, R., \& Bari, M. (2016). An ISO 9126 Based Quality Model for the e-Learning Systems. International Journal of Information and Education Technology, 370-375.

Sidik, A. (2018). Analisis Sistem Informasi Akademik (SIMAK) Berbasis ISO/IEC 9126-4 untuk Pengukuran Kualitas Penggunaan (Studi Kasus: SIMAK UIN Raden Fatah Palembang). Palembang: UIN Raden Fatah. 